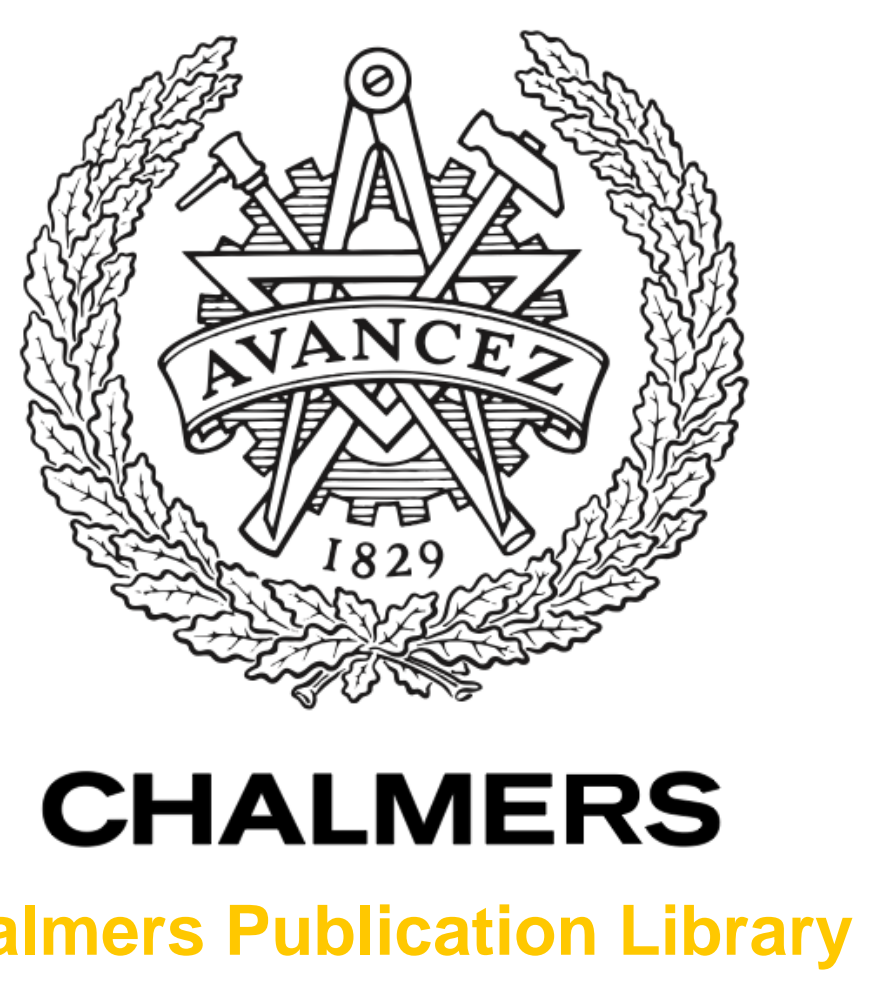

\title{
Prospects for domestic biofuels for transport in Sweden 2030 based on current production and future plans
}

This document has been downloaded from Chalmers Publication Library (CPL). It is the author's version of a work that was accepted for publication in:

WILEY Interdisciplinary Reviews, Energy and Environment (ISSN: 2041-840X)

\author{
Citation for the published paper: \\ Grahn, M. ; Hansson, J. (2015) "Prospects for domestic biofuels for transport in Sweden \\ 2030 based on current production and future plans". WILEY Interdisciplinary Reviews, \\ Energy and Environment, vol. 4(3), pp. $290 \hat{3} 306$.
}

http://dx.doi.org/10.1002/wene.138

Downloaded from: http://publications.lib.chalmers.se/publication/210761

Notice: Changes introduced as a result of publishing processes such as copy-editing and formatting may not be reflected in this document. For a definitive version of this work, please refer to the published source. Please note that access to the published version might require a subscription. 


\title{
Prospects for domestic biofuels for transport in Sweden 2030 based on current production and future plans
}

\author{
Maria Grahn ${ }^{1 *}$ and Julia Hansson ${ }^{2}$
}

Currently, Sweden has the largest share of renewable fuels for transport in the EU. The ambition of the Swedish Government for 2030 is for a vehicle fleet independent of fossil fuels. This paper assesses the potential future contribution of domestically produced biofuels for transport in Sweden to 2030, based on a mapping of the prospects from the actual and potential Swedish biofuel producers. There are plans for cellulose-based ethanol, methanol, DME (dimethyl ether), methane, and the biodiesel option HVO (hydrotreated vegetable oil). Continued domestic production of biofuels at current levels and the realization of all the ongoing mapped plans for additional biofuels production result in potential domestic biofuels production of $18 \mathrm{TWh}_{\text {fuel }}$ in 2023 . When assuming a continued expansion of biofuels production capacity, the potential domestic biofuels production reaches about $26 \mathrm{TWh}_{\text {fuel }}$ in 2030. If the realization of the mapped biofuels plans is delayed by 5 years and the pace of continued implementation of additional biofuel capacity is also reduced, the potential domestic biofuels production is reduced to about 8 $\mathrm{TWh}_{\text {fuel }}$ and $20 \mathrm{TWh}_{\text {fuel }}$ biofuels in 2020 and 2030, respectively. These two scenarios correspond to a share of biofuels of the total future energy demand for road transport in Sweden at about $10-30 \%$ in 2020 and $26-79 \%$ in 2030 , depending on which official energy demand scenario is used. The actual contribution of biofuels for road transport will depend on, e.g., policies, the global development for fossil fuels and biofuels, the competition for biomass and biofuels, and future energy demand in the road transport sector. () 2014 John Wiley \& Sons, Ltd.

How to cite this article:

WIREs Energy Environ 2014. doi: 10.1002/wene.138

\section{RENEWABLE ENERGY IN THE SWEDISH TRANSPORT SECTOR}

$\mathrm{I}^{\mathrm{n}}$ n 2012, the use of renewable energy in the Swedish transport sector amounted to $12.6 \%$ when calculated according to the so-called Renewable Energy Directive (RED) calculation rules (i.e., as share of

*Correspondence to: maria.grahn@chalmers.se

${ }^{1}$ Division of Physical Resource Theory, Department of Energy and Environment, Chalmers University of Technology, Göteborg, Sweden

${ }^{2}$ Climate \& Sustainable Cities, IVL Swedish Environmental Research Institute, Stockholm, Sweden

Conflict of interest: The authors have declared no conflicts of interest for this article. the use of gasoline, diesel, biofuels used in road and rail transport, and electricity in land transport, and with the contribution from biofuels produced from wastes, residues, nonfood cellulosic material, and lignocellulosic material considered double the actual amount). ${ }^{1,2}$ This was the largest share of renewable fuels for transport among the EU countries, ${ }^{3}$ and unless the use of renewable fuels decreases and/or the energy demand in the transport sector increases substantially or the calculation rules in the RED change, Sweden will meet the target of $10 \%$ renewable energy in the transport sector for 2020 stipulated in the RED.

Ethanol, biodiesel options (FAME, fatty acid methyl ester; HVO, hydrotreated vegetable oil) 
TABLE 1 The Use of Biofuels for Transport in Sweden in $2012^{4}$

\begin{tabular}{ll}
\hline Biofuels for Transport & $\begin{array}{c}\text { TWh (Share of Total } \\
\text { in Parenthesis) }\end{array}$ \\
\hline Ethanol & $2.4(34 \%)$ \\
of which low blending & $1.13(16 \%)$ \\
of which E85/ED95 & $1.27(18 \%)$ \\
Biodiesel & $3.73(54 \%)$ \\
of which low blending & $3.35(48 \%)$ of which FAME: \\
& 2.35 and HVO: 1.0 \\
other & $0.38(6 \%)$ \\
Biogas (million $\left.\mathrm{Nm}^{3}\right)$ & $0.8(12 \%)$ \\
\hline
\end{tabular}

and biogas are the main biofuels used for transport in Sweden; DME (dimethyl ether) and ETBE (an octane-increasing additive for gasoline that can be based on ethanol) are used in much lower volumes.

In 2012 the total use of biofuels for transport in Sweden (6.95 TWh, see Table 1) corresponded to about $8 \%$ of the total use of gasoline, diesel, natural gas, and biofuels for road transport. ${ }^{4}$ About 47\% of the ethanol was used for low blending, with the remaining share as E85 and ED95. ${ }^{4}$ About $90 \%$ of the biodiesel in the transport sector was used for low blending, and $70 \%$ of this consisted of FAME. ${ }^{4}$ Gas for vehicles is pure biogas, pure natural gas, or a mixture that varies depending on location and time of year. The share of biogas of the total gas use for vehicles amounted to about $60 \% .{ }^{4}$ More generally, the share of petrol has decreased and diesel increased in recent years. ${ }^{4}$ In total, the use of energy for domestic transport in Sweden had decreased in 2012 by 3\% compared with $2010 .^{4}$

In addition to EU policies such as RED, Sweden has and has had several different national policies stimulating the production and use of renewable fuels for transport, as well as policies for associated vehicles, e.g., energy and carbon tax exemption for renewable fuels, vehicle tax exemption for green cars (replacing a green car premium), benefits value for certain green cars, obligation for fuel retail outlets to offer renewable fuels, investment aid for biogas and other renewable gases, carbon dioxide $\left(\mathrm{CO}_{2}\right)$ differentiated annual vehicle tax, super green car premium. ${ }^{5,6}$ A quota system for biofuels for transport is expected to become operative in 2014, and the energy and carbon tax exemption rules have changed (mainly because tax exemption is more costly for the government, see Ref 7).

The ambition of the Swedish Government is for Sweden in 2030 to have a vehicle fleet that is independent of fossil fuels, e.g., by a transition to sustainable renewable fuels, major developments in electrification, and measures that reduce the demand for transport. ${ }^{8}$ The overall national vision for 2050 is a Sweden with no net emissions of greenhouse gases (GHG) to the atmosphere. A national roadmap for 2050 is being developed. ${ }^{9}$ An official survey of different options for 'fossil fuel independence' has identified measures to reduce emissions and dependence on fossil fuels in the transport sector in line with the vision for $2050 . .^{10}$

In Sweden, in 2012, slightly more than $50 \%$ of the ethanol used was produced domestically, mainly based on domestic resources. ${ }^{11}$ The remaining share originates primarily in other EU countries, and about $80 \%$ of the total ethanol use was based on cereals (primarily wheat and corn). ${ }^{12}$ Of the biodiesel (FAME and HVO) used, $68 \%$ was produced domestically. ${ }^{11}$ The FAME was primarily based on feedstocks (rapeseed) from other EU countries, and about $40 \%$ of the total use of HVO originates from Swedish raw tall oil. ${ }^{12}$ The demand for biofuels and feedstock is expected to increase further in response to EU and global targets.

A review of different kinds of existing scenarios and visions, for the contribution of biofuels in the Swedish transport sector in 2030 (e.g., Refs 9 and 13-16), shows that the contribution of biofuels in the Swedish fuel mix differs considerably among the included studies. ${ }^{6}$ In 2030, the amount of biofuels for transport in Sweden varies between 4 and 53 TWh, corresponding to $6-56 \%$ of the current energy demand for road transport in Sweden (the endpoints of the interval are represented by Refs 17 and 18). More information about the included studies can be found in Ref 6 Although the existing studies have different aims, delimitations, approach and assumptions (e.g., regarding import of biofuels) and are thus not completely comparable, the review indicates that it, as expected, is difficult to predict the possible contribution of biofuels in the future Swedish transport sector.

This study differs from existing scenarios and visions as it takes its starting point from current production and actual expansion plans made by existing and potential Swedish biofuel producers, mapped primarily through personal communication. The potential future contribution of domestically produced biofuels for transport in Sweden to 2030 is estimated from a combination of the mapped information of the prospects from the biofuel actors and scenario analysis, which takes into account uncertainties regarding the realization of the plans. Results should be of interest to policy makers and other actors evaluating the prospects for renewable fuels. In this paper the term biofuels is used to denote biofuels for transport. 


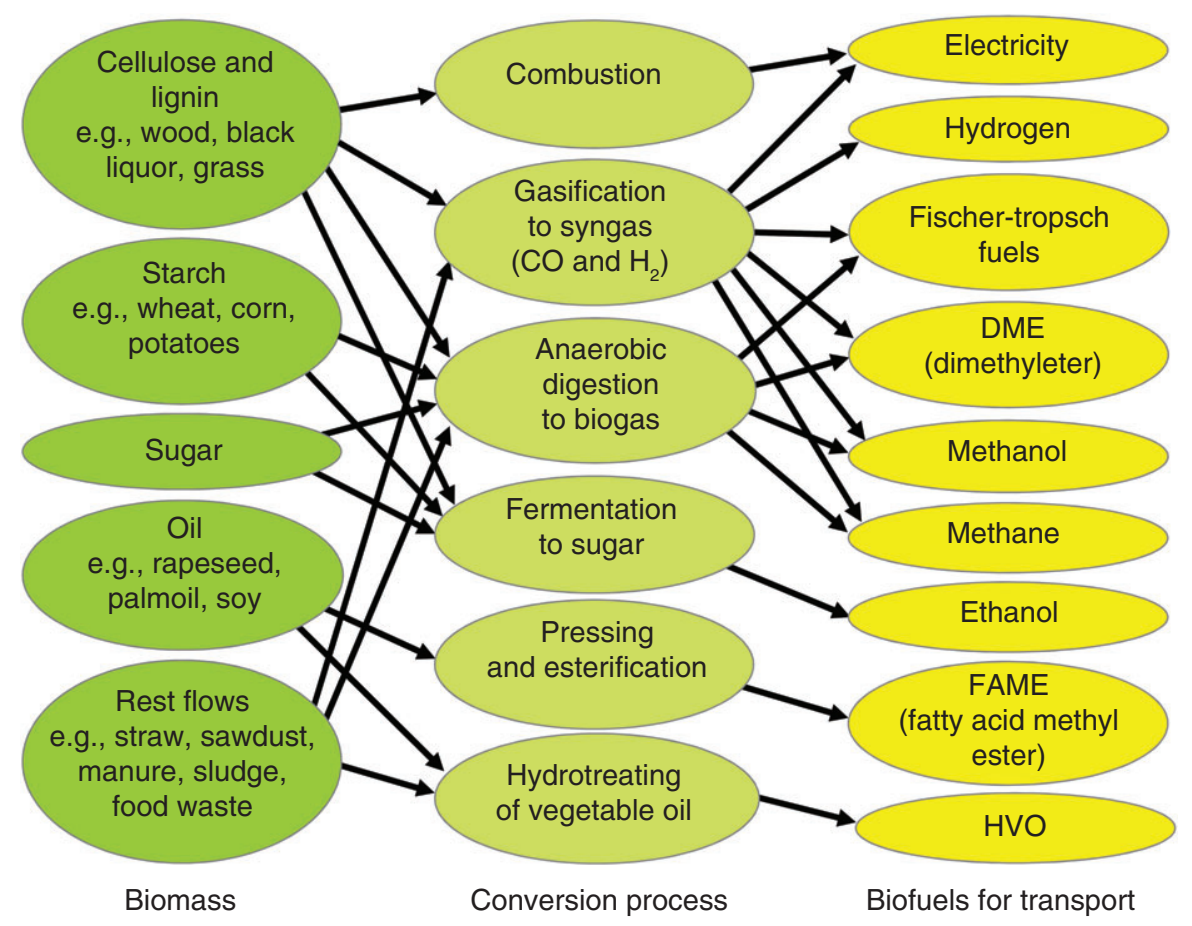

FIG URE 1 | Biofuels production options illustrating the suitable conversion processes for various kinds of biomass. To avoid making the figure too difficult to read we have chosen to exclude arrows pointing out that all types of biomass can be combusted.

\section{BIOFUEL OPTIONS}

Biomass can be categorized by chemical composition. Different elements are better suited for different processes that convert biomass into biofuels of use in the transportation sector. The main biofuels production options currently discussed in Sweden are illustrated in Figure 1.

\section{MAPPING THE PROSPECTS FOR DOMESTIC PRODUCTION OF BIOFUELS FOR TRANSPORT}

The prospects for domestic production of biofuels for transport are mapped based on contact with actual and potential Swedish biofuel producers and the relevant literature review, see also Ref 6 . The mapping was performed during 2012-2013, with some updates until February 2014. We have not assessed the probability of realizing the various biofuel plans (or the credibility of the information). Historically, Swedish biofuel producers' plans have changed (e.g., regarding size and start year); an alternative scenario is constructed to meet these uncertainties.

We have chosen to describe all types of facilities, including canceled projects as well as research and pilot plants (even if producing none or insignificant amounts of biofuels) as these indicate interest in developing biofuel conversion technologies. However, these kinds of facilities are not included in the scenarios. Note that the large number of small-scale commercial plants, producing anaerobic digestion biogas (AD biogas), are not mapped individually.

\section{Summary of Existing and Planned Production Capacity for Biofuels for Transport in Sweden}

A summary of the mapping of existing and planned production capacity for biofuels is presented in Tables 2-4. The individual facilities (among which canceled projects as well as research and pilot plants are included) are described in the following sections. In general, we have used the terms regarding status (e.g., demonstration, pilot, etc.) used by the actors.

\section{Cereal-Based Ethanol}

The domestic production capacity for cereal-based ethanol amounted to $1230 \mathrm{GWh}_{\text {fuel }}\left(210,000 \mathrm{~m}^{3}\right)$ per year in 2010, and the actual production was about $1130 \mathrm{GWh}_{\text {fuel }} /$ year $\left(194,000 \mathrm{~m}^{3}\right)$ of ethanol in 2010 and about $1100 \mathrm{GWh}_{\text {fuel }} /$ year $\left(188,000 \mathrm{~m}^{3}\right)$ ethanol in 2011 (Frida Källström, Lantmännen Energi 2012, personal communication). Currently the two Agroetanol facilities in Norrköping produce grain-based ethanol. 
TABLE 2 | Current and Planned Ethanol Production Capacity in Sweden

\begin{tabular}{|c|c|c|c|}
\hline \multirow[b]{2}{*}{ Production Facilities } & \multicolumn{3}{|c|}{ Estimated } \\
\hline & Feedstock & Capacity $\left(\mathrm{GWh}_{\text {fuel }} / \text { year }\right)^{1}$ & Actual or Planned Start \\
\hline SEKAB, Örnsköldsvik & Cellulose & 65 & 1940 \\
\hline Agroetanol 1, Norrköping & Grain & 390 & 2001 \\
\hline Agroetanol 2, Norrköping & Grain & 1130 & 2008 \\
\hline ST1, Gothenburg & Food waste & $34^{2}$ & End of 2014 \\
\hline $\begin{array}{l}\text { Nordisk Etanol och Biogas AB, } \\
\text { Karlshamn }\end{array}$ & Grain/cellulose & $770 / 1540^{3}$ & No sooner than $2015 / 2020$ \\
\hline NBE Sweden, Sveg & Cellulose & 445 & No sooner than 2015 \\
\hline $\begin{array}{l}\text { Current capacity, rounded to } \\
\text { nearest } 5 \mathrm{GWh}_{\text {fuel }} / \text { year }\end{array}$ & & $1585(65)^{4}$ & \\
\hline $\begin{array}{l}\text { Further planned capacity, rounded } \\
\text { to nearest } 5 \mathrm{GWh}_{\text {fuel }} / \text { year }\end{array}$ & & $1250-2020(480-2020)^{4}$ & \\
\hline Total current and planned capacity & & $2835-3605(545-2085)^{4}$ & \\
\hline
\end{tabular}

Two test facilities: SP demo in Örnsköldsvik and NBE Sweden in Sveg are described in the text.

${ }^{1}$ Calculated assuming $21 \mathrm{MJ} / \mathrm{L}$ ethanol in lower heating value. ${ }^{52}$

${ }^{2}$ Calculated assuming $27 \mathrm{MJ} / \mathrm{kg}$ ethanol in lower heating value. ${ }^{52}$

${ }^{3}$ The expansion plan for 2020 has grain-based ethanol being replaced by cellulose-based ethanol.

${ }^{4}$ Figures in brackets point out the cellulosic part of the summaries.

TABLE 3 | Current and Planned Production Capacity of Synthetic Fuels via, e.g., Gasification

\begin{tabular}{|c|c|c|c|}
\hline \multirow[b]{2}{*}{ Production Facilities } & \multicolumn{3}{|c|}{ Estimated Capacity } \\
\hline & Feedstock/Product & $\left(\mathrm{GWh}_{\text {fuel }} /\right.$ year $)$ & Actual or Planned Start \\
\hline LTU Green fuels Piteå (3 MW) & Black liquor/DME & 6 & 2010 \\
\hline $\begin{array}{l}\text { Göteborg Energi, GoBiGas1, Gothenburg } \\
\text { (20 MW) }\end{array}$ & Solid biomass/methane & 180 & 2013 \\
\hline $\begin{array}{l}\text { Göteborg Energi, GoBiGas2, Gothenburg } \\
\text { (100 MW) }\end{array}$ & Solid biomass/methane & 1000 & No sooner than 2016 \\
\hline Värmlandsmetanol, Hagfors (110 MW) & $\begin{array}{l}\text { Forest } \\
\text { residues/methanol }\end{array}$ & 600 & 2016 \\
\hline E.ON, Bio2Gas (200 MW) & Solid biomass/methane & 1600 & 2018 \\
\hline $\begin{array}{l}\text { Vallvik biofuel, Rottneros AB (About } 200 \\
\qquad \text { MW) }\end{array}$ & Black liquor/methanol & 750 & No sooner than 2017 \\
\hline $\begin{array}{l}\text { Rottneros biorefinery, Rottneros } A B \\
\text { (About } 200 \mathrm{MW} \text { ) }\end{array}$ & $\begin{array}{l}\text { Forest } \\
\quad \text { residues/methanol }\end{array}$ & 750 & No sooner than 2017 \\
\hline $\begin{array}{l}\text { Biorefinery Norrtorp, SAKAB et al., Kumla } \\
\quad(250 \mathrm{MW})\end{array}$ & $\begin{array}{l}\text { Forest } \\
\text { residues/methanol, } \\
\text { methane }\end{array}$ & $\begin{array}{l}1300 \text { methanol }+480 \\
\text { methane }\end{array}$ & No sooner than 2023 \\
\hline Current capacity & & 186 & \\
\hline Further planned capacity & & 6480 & \\
\hline Total current and planned capacity & & 6666 & \\
\hline
\end{tabular}

One test facility, Chalmers gasifier (4 MW), and three canceled projects Värnamo demo (18 MW), Domsjö fabriker (200 MW), and BillerudKorsnäs (200 MW) are described in the text.

Since 2010, the technical production capacity has increased to $390 \mathrm{GWh}_{\text {fuel }} /$ year $\left(67,000 \mathrm{~m}^{3}\right)$ and 1,130 $\mathrm{GWh}_{\text {fuel }}$ /year $\left(193,000 \mathrm{~m}^{3}\right)$, respectively, due to a range of improvements for a total of about 1,520 $G W h_{\text {fuel }}$ /year $\left(260,000 \mathrm{~m}^{3}\right)$.
The facility of Nordisk Etanol och Biogas AB in Karlshamn, with a planned initial production of 770 $\mathrm{GWh}_{\text {fuel }}\left(130,000 \mathrm{~m}^{3}\right)$ ethanol per year, plans to gradually increase to $1540 \mathrm{GWh}_{\text {fuel }}\left(260,000 \mathrm{~m}^{3}\right)$ ethanol per year (Mikael Runesson, Nordisk Etanol och 
TABLE 4 | Current and Planned Production Capacity of Biodiesel (FAME and HVO)

\begin{tabular}{|c|c|c|c|}
\hline Production Facilities & Feedstock & $\begin{array}{c}\text { Capacity } \\
\left(\mathrm{GWh}_{\text {fuel }} / \text { year }\right)\end{array}$ & $\begin{array}{c}\text { Actual or } \\
\text { Planned Start }\end{array}$ \\
\hline Energigårdarna facility, Karlshamn (RME') & Rapeseed & 500 & 2006 \\
\hline Perstorp, Stenungssund (RME') & Rapeseed & 1700 & 2007 \\
\hline Preem, Gothenburg (HVO²) & Tall oil & 1000 & 2010 \\
\hline Preem, Gothenburg ( $\left.\mathrm{HVO}^{2}\right)$ & $\begin{array}{l}\text { Unspecified renewable } \\
\text { sources }\end{array}$ & Up to 1000 & 2016 \\
\hline Total current capacity & & 3200 & \\
\hline Further planned capacity & & Up to 1000 & \\
\hline Total current and planned capacity & & Up to 4200 & \\
\hline
\end{tabular}

${ }^{1} \mathrm{RME}$ stands for rapeseed methyl ester, which is one type of FAME fuel.

${ }^{2} \mathrm{HVO}$ stands for hydrotreated vegetable oil.

Biogas AB, 2013, personal communication). Within about 5 years from the production start date, the plan is to partly produce ethanol based on straw or other cellulose-based feedstock. The by-products and waste will be used for biogas production (supplemented with straw, it will yield about 600 and $1000 \mathrm{GWh}_{\text {fuel }} /$ year, respectively) (Mikael Runesson, Nordisk Etanol och Biogas AB, 2013, personal communication). The environmental permit has been granted, agreements for, e.g., feedstock, energy, and digested residues have been reached, and production could start as early as 2015 (Mikael Runesson, Nordisk Etanol och Biogas AB, 2013, personal communication). The ongoing task is to find financing.

\section{Ethanol Based on Cellulose or Waste/Residues}

Domsjö Fabriker in Örnsköldsvik has produced ethanoI from cellulose in the form of sugar from the production of sulfite pulp since the 1940s. Production capacity is about $65 \mathrm{GWh}_{\text {fuel }} /$ year $\left(11,000 \mathrm{~m}^{3}\right)$. The ethanol is bought by SEKAB, but not all of it is used for transport (Lina Wännström, SEKAB, 2011, personal communication)

SEKAB E-technology AB has run a demonstration plant for cellulose-based ethanol (called Etanolpiloten as it initially was a pilot plant) since 2004, with a capacity of $1 \mathrm{GWh}_{\text {fuel }} /$ year $\left(100-150 \mathrm{~m}^{3}\right)$ ethanol per year (in part financed by the Swedish Energy Agency). The actual production has been a few dozen $\mathrm{m}^{3}$ per year. Since 2011, SEKAB E-Technology AB has phased out operation engagement due to reduced need in the context of research activities. Technical development has been successful; the next step is to commercialize and bring the developed technology to full-scale production (Sune Wännström, SEKAB, 2012, personal communication) Minor activity took place at the plant during 2012, and in spring 2013 it was announced that the plant will operate for at least another year led by SP Technical Research Institute of Sweden and supported by the Swedish Energy Agency and the Swedish Governmental Agency for Innovation Systems (Vinnova). The plan was to convert the demonstration plant into a biorefinery, Biorefinery Demo Plant. ${ }^{19}$

The experimental facility by NBE Sweden in Sveg that ran between 2008 and 2010 produced small quantities of ethanol for research purposes but is no longer in use (Lars Fritz, NBE Sweden, 2012, personal communication) NBE Sweden plans to build a full-scale ethanol plant based on forest resources integrated with a combined heat and power plant in Sveg, with a production capacity of $445 \mathrm{GWh}_{\text {fuel }} /$ year $\left(75,000 \mathrm{~m}^{3}\right)$ ethanol, but since they have a permit for production of $595 \mathrm{GWh}_{\text {fuel }} /$ year (80,000 tons), the annual production may increase over the years (Lars Fritz, NBE Sweden, 2012, personal communication). NBE Sweden estimates that their plant can operate in 2015 at the earliest, given that they receive enough funding rather promptly. It is possible that the plant will be built in steps, i.e., that the plant will not be full scale in 2015 (Lars Fritz, NBE Sweden, 2012, personal communication)

As already mentioned, the planned facility of Nordisk Etanol och Biogas AB in Karlshamn is expected to convert from cereal- to cellulose-based ethanol in 2020, if realized.

The energy company ST1 has announced plans for an ethanol plant in Gothenburg, based on by-products and waste from the food industry, to be ready by the end of 2014 and estimated to deliver 34 $\mathrm{GWh}_{\text {fuel }}$ (4500 tons) ethanol per year as well as animal feed in the form of pellets. ST1 has also indicated a potential for more ethanol production facilities in the future, but so far no figures are available (Stefan Samuelsson, ST1, 2013, personal communication). 


\section{Anaerobic Digestion Biogas}

In 2011, a total of $1473 \mathrm{GWh}_{\text {fuel }}$ of anaerobic digestion biogas (AD biogas) was produced by 233 facilities $(50 \%$ of this was produced in Skåne, Stockholm, and Västra Götaland). ${ }^{20}$ About half of the total production was upgraded (mainly biogas from wastewater treatment plants and co-digestion facilities), and the majority of this was used as transport fuel. There is still an unused potential. Kågeson and Jonsson $^{21}$ estimate the amount of biogas from digestion of by-products and waste that can be upgraded to transport fuel to be up to $2-3 \mathrm{TWh}_{\text {fuel }}$. The total potential for $\mathrm{AD}$ biogas is estimated at about 11 $\mathrm{TWh}_{\text {fuel }}$ in Ref 22 and $15 \mathrm{TWh}_{\text {fuel }}$ in Ref 23, which can be used for heat and electricity generation or upgraded and used as transport fuel.

Since AD biogas is mainly produced in numerous small facilities widely distributed in Sweden, it will generally be analyzed at the aggregate level, instead of analyzed at the level of individual facilities as the other larger biofuels production facilities. However, as already mentioned, the planned facility of Nordisk Etanol och Biogas AB in Karlshamn is expected to produce a large amount of AD biogas $\left(600 \mathrm{GWh}_{\text {fuel }} /\right.$ year in 2015 and $1000 \mathrm{GWh}_{\text {fuel }} /$ year in 2020, if realized), and the contribution from this facility will be taken into account separately.

\section{Synthetic Biofuels}

Several synthetic fuels can be produced from syngas from gasification of biomass, e.g., methanol, DME, biomethane, and Fischer-Tropsch fuels (synthetic gasoline, diesel, aviation fuels, etc.).

Gothenburg Biomass Gasification Project, GoBiGas is a project to produce biomethane by (indirect) gasification of biofuels and forestry waste, led by Göteborg Energi (and run in partnership with E.ON). An initial 20-MW facility (which is expected to deliver about $180 \mathrm{GWh}_{\text {fuel }}$ biomethane per year when tuned and the availability has reached the expected level) has been constructed in Gothenburg and started operating in October 2013 (Lars Holmquist, Göteborg Energi, 2013, personal communication). Wood pellets are gasified currently, but other biofuels and forest residues will be used. Given that this first stage is successful, the plan is to build another $100 \mathrm{MW}$ which would give nearly $1 \mathrm{TWh}_{\text {fuel }}$ biomethane per year. The second stage is expected to start operation in 2016 at the earliest (Lars Holmquist, Göteborg Energi, 2013, personal communication). GoBiGas has had financial support from the Swedish Energy Agency (maximum granted aid SEK 222 million). The second stage of GoBiGas has been selected for financial support by the EU within the NER 300 program (which could provide assistance corresponding to $50 \%$ of the incremental cost for 5 years).

E.ON also has plans to build a biomass gasification plant (Bio2G) in Sweden at about 200 MW, which given full production corresponds to about 1600 $\mathrm{GWh}_{\text {fuel }} /$ year (Björn Fredriksson Möller, E.ON, 2012, personal communication). The schedule depends on how the financial and political conditions develop. The applications for permits have been prepared and options for sites assessed; therefore, the plant could be completed and start operations about 4 years after the decision is taken, i.e., in 2018 at the earliest (Björn Fredriksson Möller, E.ON, 2012, personal communication).

Chemrec has had a demonstration plant (about $3 \mathrm{MW}$ ) for the development of DME based on gasified black liquor in Piteå, operating since 2010. Since 2011, the plant has been producing on a more regular basis, currently at 150 days per year at a production capacity of $6 \mathrm{GWh}_{\text {fuel }} /$ year [4 tons DME per day (Ingvar Landälv, Chemrec, 2012, personal communication)]. The plant has been supported by the Swedish Energy Agency (Ingvar Landälv, Chemrec, 2012, personal communication). The DME is sold to 10 DME-driven trucks that AB Volvo has developed and is testing. Since 2013, activities at the demonstration plant are led by Luleå Technical University under the name LTU Green fuels. ${ }^{24}$

For several years, until summer 2012, there was also a biofuels production project via gasification from black liquor at a full-scale (200 MW) facility in Örnsköldsvik in connection to Domsjö Fabriker, about 70 times the capacity in Pitea (based on the technology from Chemrec AB). The planned production capacity corresponded to approximately $1 \mathrm{TWh}_{\text {fuel }} /$ year (100,000 metric tons per year of DME or 140,000 tons methanol per year) (Ingvar Landälv, Chemrec, 2012, personal communication). The project had a grant from the Swedish Energy Agency with a limit of SEK 500 million (about Euro 50 million) and expected cost of more than SEK 3 billion (Ingvar Landälv, Chemrec, 2012, personal communication). In 2011, the new owners of Domsjö Fabriker, Aditya Birla Group, decided not to invest in the project owing to the lack of long-term political decisions on policy.

Vallvik Biofuel is another 200 MW biofuels production project planning to produce methanol via gasification of lignocellulose in the form of black liquor. The planned production capacity is $750 \mathrm{GWh}_{\text {fuel }}(140,000$ tons) of methanol per year. Rottneros $\mathrm{AB}$, supported by Chemrec $\mathrm{AB}$, leads this project (indicating that it builds on the technology developed by Chemrec). With conducive long-term 
political decisions and the funding needed, Vallvik Biofuel is expected to be operating in a few years, at the earliest by 2017 (Ragnar Lundberg, Rottneros $\mathrm{AB}, 2012$, personal communication). In addition, Rottenros $\mathrm{AB}$ has another $200 \mathrm{MW}$ project with Tyréns and $2 \mathrm{GenAB}$, Rottneros Biorefinery, where lignocellulose from forest biomass will be used to produce methanol by gasification. The plant is expected to be the same size as Vallvik Biofuel or somewhat larger (Ragnar Lundberg, Rottneros AB, 2012, personal communication) Provided the political climate is supportive and creates the prerequisites for funding, this plant could also be operating in a few years (Ragnar Lundberg, Rottneros AB, 2012, personal communication).

VärmlandsMetanol $\mathrm{AB}$ plans to build $\mathrm{a}$ methanol plant based on gasification of forest resources in the municipality of Hagfors (at about $110 \mathrm{MW})$. The plant is expected to produce 600 $\mathrm{GWh}_{\text {fuel }}$ of methanol per year $(375,000 \mathrm{~L}$ of methanol per day corresponding to about $137,000 \mathrm{~m}^{3}$ per year at full production); the plant will also provide district heating. ${ }^{25}$ The expected start of operations is 2016; VärmlandsMetanol is searching for funding systematically. ${ }^{25}$

BillerudKorsnäs has analyzed the possibilities for large-scale production of pyrolysis oil from forest residues at the Skärblacka pulp and paper mill, resulting in a production of $750 \mathrm{GWh}_{\text {fuel }}(160,000$ tons) of pyrolysis liquid per year. ${ }^{26}$ The pyrolysis process produces different types of hydrocarbons that can be upgraded to biofuels for transport. The project has been selected for financial support from the EU in the NER 300 program. However, in December 2013, BillerudKorsnäs announced the discontinuation of the project in its current form. Their analysis had shown that the technology is available but the present commercial conditions and in the near future are not sufficiently attractive. ${ }^{27}$ The project has been canceled.

During 2012/2013 Sakab AB (which handles hazardous waste) and VärmlandsMetanol AB, E.ON Gasification Development AB, E.ON Värme Sverige $A B$, Peab, Structor AB, and the municipality of Kumla performed a pilot study of a 250-MW biorefinery coproducing methanol, biomethane, and district heating by gasification of forest resources as wood chips as well as by-products and waste (Biorefinery Norrtorp). There are three different output options proposed, either (1) $1700 \mathrm{GWh}_{\text {fuel }}$ (300,000 tons) of methanol per year; (2) $1300 \mathrm{GWh}_{\text {fuel }}$ methanol per year and 480 $\mathrm{GWh}_{\text {fuel }}$ of biomethane per year, or (3) $1800 \mathrm{GWh}_{\text {fuel }}$ of biomethane per year (Raimo Huhtala, Sakab AB, 2012, personal communication). The plant is planned in connection to the industrial area of Sakab $\mathrm{AB}$ in Kumla, but the next step is an economic analysis. Given a decision to proceed with the project and the necessary funding, the plant could operate commercially in about 10 years, no sooner than 2023 [Raimo Huhtala, Sakab AB, 2012, personal communication; Erik Rensfelt, Växjö Värnamo Biomass Gasification Centre (VVBGC) 2012, personal communication].

Växjö Värnamo Biomass Gasification Centre, VVBGC, and its 18-MW biomass gasification plant in Värnamo are state-owned through a holding company of Linnaues University. After upgrading and restart during the EU-project CHRISGAS 2004-2010, the plan was to transform the plant into a flexible research, demonstration, and training unit (Margareta Thyselius, VärmlandsMetanol, 2012, personal communication). The Swedish Energy Agency had planned to finance part of the reconstruction and the first project (gasification of biomass to syngas), provided industry also invested. When this failed, the Swedish Energy Agency decided to stop financial support in 2011, and the facility is currently not in use.

At Chalmers University of Technology, an indirect fluidized bed gasifier, with a capacity of $2-4 \mathrm{MW}$, was connected to an already existing $12 \mathrm{MW}$ circulating fluidized bed boiler in 2008, with the boiler acting as a heat source for the integrated gasifier. The purpose of the facility is to prove the reliability of the integration concept and test different types of solid fuels. ${ }^{28}$ Produced biofuels are for research purposes only and not used as transportation fuels.

Plants not included in this overview are, e.g., the following two small-scale facilities: (1) the pilot plant for pressurized entrained flow biomass gasification (PEBG) of biomass particles from forest residues that has been assessed at ETC, Pitea ${ }^{29}$ and (2) the indirect gasification technology Woodroll in Köping (at 150 $\mathrm{kW}$ developed by Cortus). The plan for a 5-MW Woodroll gasifier, with upscaling to $25 \mathrm{MW}$ in a second ste ${ }^{26}$, is neither part of the overview owing to lack of information.

\section{Biodiesel: FAME}

There are several producers of FAME in Sweden (e.g., Perstorps BioProducts $\mathrm{AB}$, Energigårdarna Eslöv/Ecobränsle, Karaby bioenergi HB, Norups gård $\mathrm{AB}$, and SoilOil i Häckeberga $\mathrm{AB}$ ); however, only two are relatively large. The facility of Perstorp in Stenungssund has a yearly production capacity of about $1700 \mathrm{GWh}_{\text {fuel }} /$ year $\left(180,000 \mathrm{~m}^{3}\right)$ and the facility of Energigårdarnas/Ecobränsle in Karlshamn has a yearly production capacity of about $500 \mathrm{GWh}_{\text {fuel }} /$ year $\left(50,000 \mathrm{~m}^{3}\right)$, but neither one has 
produced at full capacity in recent years ${ }^{5}$ (Christian Bundy, Ecobränsle, 2012, personal communication; Susanne Eckersten, Perstorp BioProducts, 2012, personal communication). In 2011, the production from Perstorp in Stenungsund amounted to about $1200 \mathrm{GWh}_{\text {fuel }} /$ year $\left(126,000 \mathrm{~m}^{3}\right)$ and the production from Energigårdarnas/Ecobränsle amounted to $65 \mathrm{GWh}_{\text {fuel }} /$ year $\left(7,000 \mathrm{~m}^{3}\right)$ (Christian Bundy, Ecobränsle, 2012, personal communication; Susanne Eckersten, Perstorp BioProducts, 2012, personal communication). Perstorp reports that one reason for not producing at full capacity is that the FAME fuel quality that is suitable for the Nordic climate (low content of monoglycerides) requires facilities to be run at a slower pace. The facility in Karlshamn reports that after a total stop in 2008, the annual production has increased each year, since the facility started to operate again in 2009, and production has been adjusted to the demand. The majority of the feedstock for the domestic FAME production is imported rapeseed. ${ }^{12}$

There seems to be no new plans for future biodiesel facilities in Sweden. Instead, some of the small producers stopped producing in 2012 and 2013 (Carl-Johan Andersson, Soiloil, 2012, personal communication). The future for FAME in Sweden will depend on the outcome of discussions on how to include indirect land use change in the EU sustainability criteria for biofuels; FAME might not meet the future requirements for reduced climate impact.

\section{Biodiesel: HVO}

HVO (hydrotreated vegetable oil) is a form of biodiesel that can be produced in a separate facility and by an integrated process in petroleum refineries resulting in a biomass-based share of the conventional fossil-based fuel. Biological oils, such as raw tall oil and slaughter waste, are used for HVO production, but given proper pretreatment many other feedstocks, e.g., straw, manure, algae, by-products, and waste from forest and pulp, and all kinds of biological oils can be used (Thomas Ögren and Helene Samuelsson, Preem, 2012, personal communication).

The Swedish HVO based on raw tall oil is produced in two steps. First the intermediate product raw tall diesel is separated from the raw tall oil, in a Sunpine facility (Johan Lundbäck, Sunpine, 2012, personal communication). Then the raw tall diesel is processed further to HVO diesel fuel by Preem.

The Swedish production of $\mathrm{HVO}$ from raw tall oil amounted to about $670 \mathrm{GWh}_{\text {fuel }}(67,000$ $\mathrm{m}^{3}$ ), in 2011 (Thomas Ögren and Helene Samuelsson, Preem, 2012, personal communication). The production capacity, for HVO based on raw tall oil, at Preem is $1000 \mathrm{GWh}_{\text {fuel }}\left(100,000 \mathrm{~m}^{3}\right)$ of $\mathrm{HVO}$ diesel per year (Thomas Ögren and Helene Samuelsson, Preem, 2012, personal communication). The total Swedish production of raw tall oil corresponds to about 2-2.5 TWh (Swedish Forest Industries Federation (Lina Palm, Skogsindustrierna, 2012, personal communication). This corresponds to about 1.3-1.75 TWh raw tall diesel (with negligible energy losses in the last conversion step this representing the theoretical maximum level of $\mathrm{HVO}$ from domestic tall oil). With a larger share of sustainable and acceptable feedstock for HVO, the Swedish production of HVO could increase; Preem recently announced that they will almost double their HVO production by 2016 using different types of renewable sources. ${ }^{30}$

\section{Other Biofuels for Transport under Development}

Biofuels based on algae and synthetic fuels produced from biomass-based $\mathrm{CO}_{2}$ and water using electricity as the main energy source, so-called electrofuels, are examples of biofuels that have a great supply potential but currently need further research and development before being available at large scale. $\mathrm{CO}_{2}$ released in the production of biofuels comes in a pure and concentrated form, which makes it advantageous to use in the production of electrofuels. The most discussed types of electrofuels are methane (a concept denoted 'power-to gas') or methanol (which can be converted into DME) and the most discussed algae-based biofuels are methane or FAME fuels.

The vehicle industry is interested in electrofuels (not only biomass-based). For example, Audi has invested in a power-to-gas facility in Werlte, Germany, that opened in 2013 with a production capacity of $10 \mathrm{GWh}_{\text {fuel }}$ (1000 tons) of synthetic methane per year ${ }^{31}$ and Volkswagen recently highlighted electrofuels in the form of methane as an important future complement to conventional natural gas and other biomass-based methane. ${ }^{32}$ See Refs 33 and 34 for more on electrofuels. The interest in converting fast-growing algae into biofuels has increased, in, e.g., in the United States, where a large number of companies (e.g., Exxon Mobile, Shell, and BP) have declared themselves to be in the algae business. ${ }^{35}$ See Ref 36 for more on algae-based biofuels.

The petrochemical sector is also studying other options for large-scale production of biofuels in the form of fossil fuels with substantial renewable content. One concept studied by, e.g., Preem involves lignin-derived bio-oils and pyrolysis oils. ${ }^{37,38}$ Conversion of lignin precipitate to a bio-oil that in turn can 
be fed into the refinery is between the laboratory and pilot scales, implying that it will not be realized for more than a decade. ${ }^{37}$

As there are still large uncertainties about these biofuel pathways, they are not included in the analysis of this study.

\section{SCENARIOS FOR BIOFUELS PRODUCTION IN SWEDEN UNTIL 2030}

The mapping of existing and planned production capacity for biofuels for transport in Sweden shows that many different types of biofuels are produced currently or are planned to enter the market during the coming decade. There are plans for the production of cellulose-based ethanol, methanol, DME, methane, $\mathrm{HVO}$ as well as AD biogas. We use this overview as a basis for developing scenarios for potential biofuels production in Sweden until 2030.

The large numbers of small-scale commercial plants that make up the expansion of AD biogas are generally analyzed at the aggregate level, whereas the large-scale plants that make up the expansion of other biofuel systems are analyzed individually. We construct two scenarios to represent two different plausible outcomes, where we in Scenario 1 assume that all ongoing mapped plans for additional biofuels production are realized and that the expansion continues, whereas we in Scenario 2 illustrate a less ambitious alternative where producers' plans are delayed combined with a slower expansion pace. Detailed information for the scenarios is given below.

In both scenarios, already existing facilities (apart from noncommercial research facilities and terminated projects) are assumed to continue to deliver the current amounts of biofuels during the entire time period. However, we are aware that proposed changes in biofuel policies may cause difficulties for a few existing fuel options to meet future restrictions and may lead to some existing facilities being phased out. Currently, the EU is considering developing policies related to the GHG performance of a biofuel's entire life cycle (this would include factors for indirect land use change, iLUC, and a stricter level for GHG reductions as well as limiting the use of crop-based biofuels). Such policies may affect the eligibility of, first and foremost, FAME fuels, see for example the proposal for an amendment of the RED and the Fuel Quality Directive ${ }^{39}$ from the EU Commission. ${ }^{40}$ The causes behind land use change are multiple, complex, interlinked, and change over time (cf. Refs 41 and 42), leading to uncertain quantifications and making related policy development a complex task. The second scenario, though represent a precautious future where different factors, including policies, may change the prerequisites and delay investments.

In both scenarios, all biofuels produced are assumed to be used in the road-based transport sector. All planned facilities are assumed to produce the amount of biofuels per year reported by the actors. In reality, the annual biofuels production could be somewhat reduced if the production capacity is not used to the expected extent. Further, it is assumed that biomass supply potential is not a limiting factor for the levels of biomass used in these scenarios until 2030, but this will be discussed. It is important to understand that neither of the scenarios are predictions of what will happen; they illustrate how biofuels production could develop under different assumptions.

\section{Scenario 1: Full Realization and Continued Expansion}

In Scenario 1, all planned facilities are assumed to be realized and start to produce the stated amount of biofuels in the year reported by the actors, and existing biofuel facilities are assumed to remain in production at current levels until 2030 (production from noncommercial research facilities and terminated projects are not included in the scenarios). Current production along with the realization of the production plans results in a potential contribution of almost 18 $\mathrm{TWh}_{\text {fuel }}$ in 2023. However, in Scenario 1, besides the implementation of the planned investments, slightly different continued expansion paths for the different types of biofuels are assumed. In the mapping of production plans, no indications for investment plans for grain-based ethanol or crop-based FAME fuels were identified. Therefore, the growth rates for these two biofuel options are set to zero, and they will thus remain at current size during the entire time period, in both scenarios. As described above, AD biogas is treated differently than the other biofuels: the numerous small-scale commercial plants are not analyzed individually but at the aggregate level. For AD biogas upgraded to fuel quality for transport, an increase by $10 \%$ per year until 2030 is assumed. In addition to this growth assumption, the specific contribution from the facility of Nordisk Etanol och biogas is added. This will lead to an AD biogas use of approximately $5 \mathrm{TWh}_{\text {fuel }}$ in the Swedish transport sector, in 2030, which is in line with the assumptions in Refs 22 and 23 that roughly half of the produced AD biogas will continue to be upgraded to transport fuel quality. For remaining biofuels production options, we assume $5 \%$ growth per year. An S-curve describes the technological maturity of a product, i.e., how fast new technologies enter the market, from the first laboratory phase, 
through different growth phases such as introduction, expansion, break through until fully commercialized. The choice of growth rates, 5 and $10 \%$, comes from a rough estimation of where on the S-curve the different fuel options are.

As start year, for the continued expansion of each type of biofuels production, the year after the last planned facility is ready to operate is chosen, indicating that no new facilities will be built earlier than that, if not currently planned. The assumed start year and growth factor for each biofuel type is presented in Table 5, where the amount of biofuels in the start year as well as the result for 2030 can also be found. Figure 2 shows the results for the development of domestic biofuels production for the entire time period.

The decrease of grain-based ethanol, in 2020, is because the facility 'Nordisk Etanol och Biogas' is assumed to change from grain-based ethanol to cellulose-based ethanol in 2020 (applies also to Scenario 2).

In Scenario 1, the potential contribution from domestically produced biofuels amounts to approximately $16 \mathrm{TWh}_{\text {fuel }}$ and $26 \mathrm{TWh}_{\text {fuel }}$ in Sweden in 2020 and 2030, respectively (the contribution from crop-based fuels remains below $4 \mathrm{TWh}_{\text {fuel }}$ during the entire time period). Assuming a conversion efficiency from biomass to biofuels of roughly $50 \%$ implies that approximately 30 and 50 TWh of biomass feedstocks are needed for the domestic production of biofuels for transport in Sweden in 2020 and 2030, respectively. For comparison, the total use of biofuels for transport in the EU in 2012 corresponds to about 170 TWh. $^{3}$

\section{Scenario 2: Delayed Full Realization and Slower Continued Expansion}

From experience, we know that Swedish biofuel projects sometimes are delayed by several years. ${ }^{6}$ In Scenario 2, we assumed that the start year for all ongoing planned facilities is delayed by 5 years and that investments in, and implementations of, subsequent additional biofuels production after the planned facilities follow a slower pace until 2030. Delayed full realization and slower continued expansion could be the result of general instabilities in the economic system as well as uncertainties in how biofuel policies will be designed.

The assumptions for the continued expansion of biofuels production after the realization of the mapped production capacities in Scenario 2 are presented in Table 6. The results for 2030 are presented in Table 6, while results for the entire time period are shown in Figure 3.
In Scenario 2, the potential contribution of domestically produced biofuels amounts to approximately $8 \mathrm{TWh}_{\text {fuel }}$ and $20 \mathrm{TWh}_{\text {fuel }}$ biofuels in Sweden in 2020 and 2030, respectively (the contribution from crop-based fuels again remains below $4 \mathrm{TWh}_{\text {fuel }}$ during the entire time period). Assuming a conversion efficiency from biomass to biofuels of $50 \%$ implies that approximately 15 and 40 TWh of biomass feedstocks are needed for the domestic production of biofuels for transport in Sweden in 2020 and 2030, respectively.

The assumption that the start year for all planned facilities is delayed by 5 years is rather arbitrary, and if the start year for all planned facilities instead were 10 years delayed, and the development thereafter follows the same pattern as in Scenario 2, the potential contribution of domestically produced biofuels would be $6 \mathrm{TWh}_{\text {fuel }}$ and $15 \mathrm{TWh}_{\text {fuel }}$ in 2020 and 2030, respectively.

\section{Potential Biofuel Share of Total Energy Demand for Swedish Road Transport}

In order to compare the estimated potential contribution of domestic biofuels with the total future energy demand for road transport in Sweden, an estimation of the latter is needed. The actual energy demand for road transport will depend on, e.g., the development of energy efficiency related to transport and behavioral change related to energy use. Recent official estimations of the energy demand for road transport in Sweden in 2020 and 2030, generated by Swedish authorities, but with different approaches and aims, can be found in Refs 14 and 43. Both these estimations will be used for the comparison.

Demand Scenario A, based on Ref 43, represents a long-term prognosis based on current vehicle trends as well as policies. Demand scenario B, based on Ref 14, represents a situation in which Sweden focuses on meeting the vision of no net emissions of GHG to the atmosphere by 2050. Energy demand scenario B represents a relatively low energy demand, which is motivated by the implementation of measures promoting energy efficiency, as well as reducing the demand for transport, and includes a substantial contribution from electric vehicles. Demand scenario A represents a higher energy demand and includes a limited amount of electric vehicles. The actual energy demand for road-based transport estimated in the two different demand scenarios for 2020 and 2030 are presented in Table 7. Table 7 also presents the shares of the energy demand for Swedish road transport to which the potential domestically produced biofuels estimated in Scenarios 1 and 2 correspond. Depending on the biofuel scenario and demand scenario, the 
TABLE 5 Scenario 1 Assumptions for the Continued Expansion of Domestic Biofuels Production after Planned Investments, as well as the Results for 2030

\begin{tabular}{|c|c|c|c|c|}
\hline & Start Year ${ }^{1}$ & $\begin{array}{l}\text { Growth } \\
\text { Factor }\end{array}$ & $\begin{array}{c}\text { Amount of } \\
\text { Biofuels in Start } \\
\text { Year ( } \mathrm{TWh}_{\text {fuel }} / \text { year) }\end{array}$ & $\begin{array}{c}\text { Amount of } \\
\text { biofuels } 2030 \\
\left(\mathrm{TWh}_{\text {fuel }} / \text { year }\right)\end{array}$ \\
\hline Ethanol grain & 2013 & 0 & 1.5 & 1.5 \\
\hline Ethanol cellulose + waste & 2021 & 1.05 & 2.1 & 3.4 \\
\hline FAME & 2013 & 0 & 2.2 & 2.2 \\
\hline HVO & 2017 & 1.05 & 2.0 & 4.0 \\
\hline Biogas (anaerobic digestion) & 2014 & 1.10 & 0.8 & $5.1^{2}$ \\
\hline Biomethane & 2024 & 1.05 & 3.3 & 4.6 \\
\hline DME/methanol & 2024 & 1.05 & 3.4 & 4.8 \\
\hline
\end{tabular}

${ }^{1}$ The year after the last planned facility, indicating that no facilities will be built earlier if not currently planned.

${ }^{2}$ Apart from the growth at the aggregate level, individual contributions from cogenerated AD biogas in the facility of Nordisk Etanol och biogas are added in 2015 and 2020 .

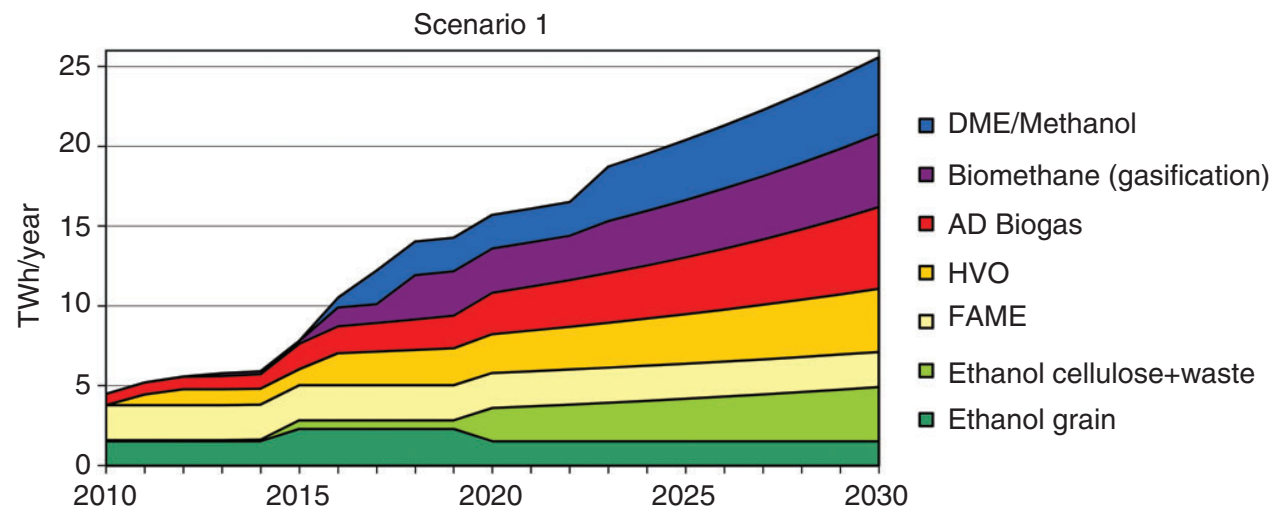

FI U UE 2 | Domestically produced biofuels for transport in Sweden 2010-2030, in Scenario 1, based on current production, the realization of future plans, and with assumptions for the implementation of subsequent additional biofuels production.

potential biofuel share of the total energy demand for road transport is $10-30 \%$ in 2020 and $26-79 \%$ in 2030. The high ends of the intervals represent the estimated energy demand for road transport if Sweden is to meet the national vision of no net emissions of GHG to the atmosphere in 2050. The wide range within the intervals indicates that the possible future biofuel share, to a high degree, depends on the estimated total future energy demand, which is very uncertain.

\section{DISCUSSION}

Owing to its policy measures, ${ }^{6}$ Sweden had the largest share $(12.6 \%)$ of renewable fuels for transport among EU countries in 2012 (calculated according to the RED). In this paper, we have assessed the potential future contribution of domestically produced biofuels for transport in Sweden by 2030, based on our mapping of existing and planned domestic production capacity for biofuels and developing two potential biofuels production scenarios.

Mapping exercises always deliver a snapshot of reality, in this case how actual and potential Swedish biofuel producers, during 2012-2013, viewed the prerequisites for their future biofuels production (and how this information was shared and available to the authors). In reality, plans often tend to change with time, which is illustrated to a limited extent in our Scenario 2. We have not assessed the probability that a given biofuel plan will be realized (or the credibility of the information), and we have not analyzed the probabilities for the different scenarios to be realized, as it is difficult to predict which plans will be realized (and when) and what plans might be added. However, the information has been compared and checked with other references when available. The authors have for example been involved in the governmental investigation on fossil fuel independence in the Swedish transport sector in which Swedish 
TABLE 6 | Scenario 2 Assumptions for the Continued Expansion of Domestic Biofuels Production after Planned Investments, as well as the Results for 2030

\begin{tabular}{|c|c|c|c|c|}
\hline & Start (year) ${ }^{1}$ & $\begin{array}{l}\text { Growth } \\
\text { Factor }\end{array}$ & $\begin{array}{c}\text { Amount of } \\
\text { Biofuels Start } \\
\text { Year (TWh } \text { fuel } / \text { year) }\end{array}$ & $\begin{array}{c}\text { Amount of } \\
\text { Biofuels } 2030 \\
\text { (TWh }{ }_{\text {fuel }} / \text { year) }\end{array}$ \\
\hline Ethanol grain & 2013 & 0 & 1.5 & 1.5 \\
\hline Ethanol cellulose + waste & 2026 & 1.025 & 2.1 & 2.7 \\
\hline FAME & 2013 & 0 & 2.2 & 2.2 \\
\hline HVO & 2022 & 1.025 & 2.0 & 3.1 \\
\hline Biogas (anaerobic digestion) & 2019 & 1.050 & 0.8 & $3.6^{2}$ \\
\hline Biomethane & 2029 & 1.025 & 3.3 & 3.6 \\
\hline DME/methanol & 2029 & 1.025 & 3.4 & 3.8 \\
\hline
\end{tabular}

${ }^{1}$ In this scenario it is assumed that the realization of the planned biofuels production capacity will be delayed by 5 years compared to reported plans (setting years 2014-2019 identical to 2013).

${ }^{2}$ Apart from the growth at the aggregate level, individual contributions from cogenerated AD biogas in the facility of Nordisk Etanol och biogas are added in 2020 and 2025.

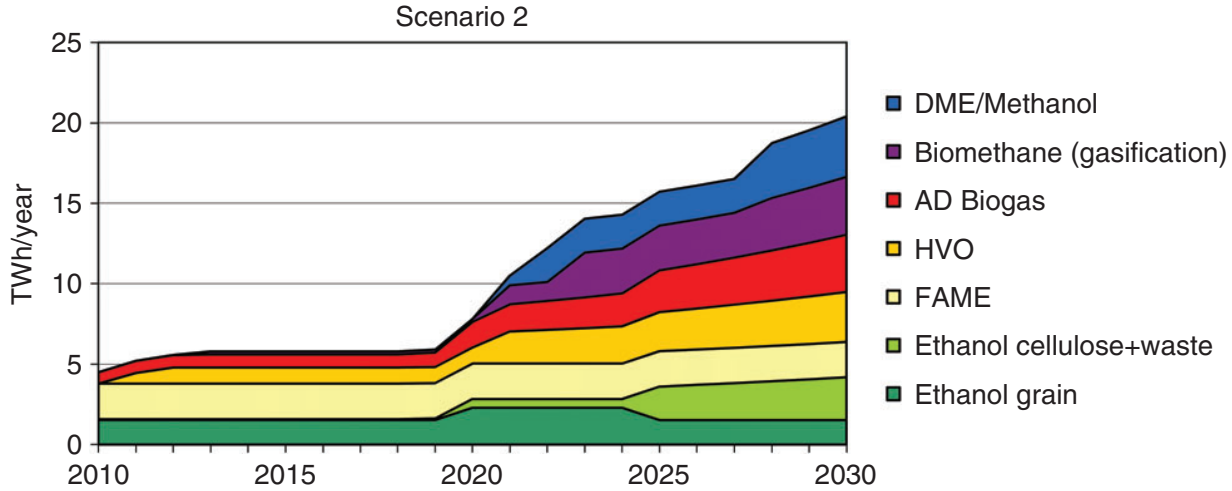

FIG URE 3 | Domestically produced biofuels for transport in Sweden 2010-2030 based on current production, the realization of future plans and a slower pace for the implementation of subsequent additional biofuels production. All plans are assumed to be delayed by 5 years compared to what is currently reported.

biofuel actors have provided and checked the same information. ${ }^{10}$ Changes in a biofuel producer's plans (e.g., regarding size, start year, and status) will influence the estimation of potential future contribution of domestically produced biofuels. Some of the included potential biofuels production may not be realized or be replaced by other projects. However, our study is of interest to policy makers and other actors evaluating the prospects for renewable fuels.

Compared to a similar assessment of the prospects for Swedish production of biofuels for transport made during 2009-2010, ${ }^{44}$ there are some new projects, but most of the projects known in 2010, are still active, although the time tables for building the facilities generally have been somewhat delayed, for example, the facilities by NBE Sweden, Nordisk Etanol och Biogas AB, ST1, and VärmlandsMetanol $\mathrm{AB}$. The actors mainly refer to global economic instabilities limiting investments as the reason for the delay. In general, according to the biofuel industry actors, in particular the lack of long-term political decisions has prevented a more progressive development of biofuels production in Sweden (long-term economic support is demanded), not the pace of technology development. Political signals (including international signals) influence the possibility to obtain funding. The lead time for developing biofuels production facilities (including building permits, environmental permits, etc.) is also of importance. ${ }^{6}$

Some existing biofuel technologies are not seen in the scenarios in this study, for example, Fischer-Tropsch (FT) fuels. No Swedish plans for FT were identified in the mapping exercise. However, for the time period beyond currently planned facilities, FT fuels (or other types of biofuels) could replace the types of biofuels currently shown in the scenarios. The scenarios also do not show a contribution from algae-based biofuels, biomass-based electrofuels, or other biomass-based fuel technologies that currently are in an early phase of development. 
TABLE 7 | Estimated Potential Biofuels Production Capacity in the Two Biofuel Scenarios (1 and 2) Compared to Two Different Estimations of the Future Energy Demand (A and B) for Swedish Road Transport in 2020 and 2030

\begin{tabular}{|c|c|c|c|c|}
\hline & \multicolumn{2}{|c|}{ Biofuel Scenario 1} & \multicolumn{2}{|c|}{ Biofuel Scenario 2} \\
\hline & 2020 & 2030 & 2020 & 2030 \\
\hline Biofuels production capacity (TWh/year) & 16 & 26 & 8 & 20 \\
\hline Demand scenario A (TWh/year) ${ }^{1}$ & 80 & 78 & 80 & 78 \\
\hline Demand scenario B (TWh/year) $)^{2}$ & 54 & 33 & 54 & 33 \\
\hline $\begin{array}{l}\text { Comparison A. Biofuel share of energy } \\
\text { demand for Swedish road transport, } \\
\text { assuming demand A }\end{array}$ & 0.20 & 0.33 & 0.10 & 0.26 \\
\hline $\begin{array}{l}\text { Comparison B. Biofuel share of energy } \\
\text { demand for Swedish road transport, } \\
\text { assuming demand B }\end{array}$ & 0.30 & 0.79 & 0.15 & 0.61 \\
\hline
\end{tabular}

For Comparison, the energy demand for Swedish road transport was approximately 84 TWh in $2012 .{ }^{4}$

${ }^{1}$ Reference scenario for the long-term prognosis in Ref 43.

${ }^{2}$ Scenario 1 in Ref 14.

If these technologies develop at a more rapid pace before 2030 than currently expected, the potential contribution for domestically produced biofuels in Sweden for 2030 may exceed the estimations we have presented.

Not all the domestically produced biofuels will necessarily be used in the Swedish road transport sector. The demand for biofuels from other transport sectors, such as sea-based transport and aviation, as well as demand from the chemical industry, could increase, see e.g., Refs 45-47. For road transport, it is possible to use vehicles driven by hydrogen or electricity as a complement to biofuels, when goals for reduced $\mathrm{CO}_{2}$ emissions are to be achieved. But from a technical perspective, it is considered more challenging to use electricity and hydrogen for sea-based transport and aviation. Therefore, the domestically produced amounts of biofuels may be used in other end-use sectors in Sweden as well as in other countries.

Sweden currently imports considerable amounts of biofuels for transport per year (approximately 3 TWh/year in 2011). ${ }^{48}$ However, the future contribution from import of biofuels for transport is uncertain, and Sweden is sometimes considered a potential export country for biofuels for transport. ${ }^{14}$ For simplicity, we compared the total estimated biofuels production potential to the estimated future Swedish road transport demand. This exercise should not be interpreted as suggesting there will be no export of Swedish biofuels in the future. Market prices will likely determine where the biofuels end up. There could also be an increased demand for biomass from the heat and power sector, aiming to reduce the use of fossil fuels, limiting the amount of biomass that is available for the transport sector.
Are the domestic biomass resources approximately sufficient to meet the estimated potential biofuels production? The latest estimate of the Swedish additional biomass supply potential (available for energy) reports 50-60 TWh of additional biomass per year in the short term and at least 75-90 TWh in 30-50 years. ${ }^{10,26}$ The estimated potential biofuels production corresponds to approximately $15-50 \mathrm{TWh}$ per year of biomass, in the period 2020-2030. That scenario also represents a substantial increase compared with the present biomass use for transport in Sweden. In 2010, the Swedish use of biofuels for transport corresponded to approximately $10 \mathrm{TWh}$ of biomass of which slightly more than 2 TWh was domestically produced. ${ }^{5}$ However, it seems that the estimated domestic biomass supply could meet the estimated demand from domestic biofuels production, at least in theory.

Of the estimated 50-60 TWh of additional biomass per year (potentially available for energy) in Sweden, the majority could be in the form of lignocellulosic and waste feedstock (however, some amount of the underlying agricultural area could also be used to produce grain and other more traditional agricultural crops). ${ }^{10,26}$ The underlying estimation assumes a mix of energy crops. The estimated potential biofuels production corresponds roughly to a biomass demand of approximately 32-43 TWh lignocellulosic and waste feedstock in 2030, while the production of grain-based ethanol and FAME does not increase in 2030 compared with that in 2010. For comparison, the overall environmentally compatible biomass supply potential in Sweden in 2030 is estimated to be about 157 TWh in Ref 49.

In reality, all land-using activities will impact the bioenergy supply potential. Apart from food, feed, 
and grazing, the competition for biomass and biofuels from other sectors, as well as the demand for biofuels in other countries, will influence how large share of the domestic biomass supply potential is used for domestic biofuels production in the future. The location of the biofuel facilities in relation to the location of the biomass supply is also of importance.

The actual contribution of biofuels for road transport in Sweden in the future will depend on many factors, such as the development of policies (national as well as at the EU level), global developments for fossil fuels and biofuels, the future energy demand, the production and distribution costs for biofuel facilities, the possibility for the Swedish vehicle fleet to use the produced biofuels, and the global competition for biomass and biofuels. The future for Swedish biofuels production will for example depend on if there is support for new domestic biofuels production as proposed in Ref 10.

The fuel infrastructure and the vehicle fleet may limit the amount of new types of fuels used. Some of the fuel types may be used as blends in conventional fuels, but it is challenging to blend in more than $10-20 \%$, to meet biofuel shares higher than that, modified vehicles need to enter the market. The average lifespan for cars in Sweden is 17 years ${ }^{50}$, meaning that the majority of cars sold today will still be around in 2030, unless incentives are introduced to phase out vehicles at a more rapid pace. In January 2012, there were in total 2885 fuel stations in Sweden. ${ }^{51}$ Fuel infrastructure is well developed (1694 locations) ${ }^{51}$ for the fuel blend E85 (85\% ethanol and $15 \%$ gasoline) mainly as a result of a Swedish law requiring fuel stations of a certain size to supply at least one renewable fuel. The developed E85 infrastructure, in combination with a well-established low-blend market, indicates that the ethanol production seen in our scenarios will not be limited by infrastructure. In 2012, most HVO-diesel blends were a mix of $23 \% \mathrm{HVO}$ and $7 \%$ FAME in conventional diesel, available at more than 700 locations. ${ }^{6}$ There are no technological limitations for the share of HVO that a diesel engine can run on, which indicates that the HVO production seen in our scenarios will not be limited by existing infrastructure. For methane, DME, and pure FAME fuels, there is some current infrastructure (132, 4, and 22 locations respectively) ${ }^{51}$. An expansion of methane and DME requires new infrastructure to be built. A drawback for methane is the relatively costly distribution system. In Sweden, no methanol is currently used in the road transport sector. However, it is possible to blend 3\% methanol in gasoline, and adjusted vehicles can run on
M85 or M100. To be able to use the methanol shown in the scenarios, new infrastructure needs to be built.

The contribution of the estimated potential biofuels production to the total Swedish energy demand for transport depends to a large extent on how energy demand develops, which differs considerably among studies. Achieving the estimated energy demand in Ref 14 requires a relatively large adjustment of the transport sector.

Finally, we have not assessed the investment costs associated with each of the mapped biofuel plans or the need for investors and other funding possibilities, but this is an interesting task for future analyses.

\section{CONCLUSION}

In addition to current biofuels production (mainly wheat-based ethanol, rapeseed-based FAME, AD biogas, and HVO based on tall oil), there are plans for cellulose-based ethanol, food waste-based ethanol, methane, methanol, and further expansion of HVO production in Sweden. Some of the projects have been delayed relative to the original plans. In particular, the lack of long-term political decisions, not limits in technology development, is what has prevented a more progressive development of biofuels production in Sweden, according to the Swedish biofuel industry actors.

The potential domestic Swedish biofuels for transport production is approximately $18 \mathrm{TWh}_{\text {fuel }}$ in 2023, assuming continued domestic production of biofuels at current levels and the realization of all the ongoing mapped plans for additional biofuels production. The potential domestic biofuels production reaches about $26 \mathrm{TWh}_{\text {fuel }}$ in 2030 with an assumed continued expansion of biofuels production. For comparison, the current Swedish energy demand for road-based transport is approximately $84 \mathrm{TWh} .{ }^{4}$

The estimated potential domestic Swedish biofuels production corresponds to about $20-30 \%$ in 2020 and $33-79 \%$ in 2030 of the future Swedish energy demand for road transport, when comparing with two official scenarios representing distinctly different developments of the transport and related energy demand.

However, if the realization of the mapped biofuels plans is delayed, canceled and/or the continued implementation of additional biofuel capacity is slower than assumed above, the potential domestic biofuels production in Sweden is reduced substantially. 


\section{REFERENCES}

1. Government Offices of Sweden. Sweden's second progress report on the development of renewable energy pursuant to Article 22 of Directive 2009/28/EC, 2013. Members States' progress reports, 2013 reports translated in English. Available at: http://ec.europa.eu/ener gy/renewables/reports/2013_en.htm. (Accessed May 3, 2014).

2. European Parliament and Council. Directive 2009/28/EC of the European Parliament and of the council of 23 April 2009 on the promotion of the use of energy from renewable sources and amending and subsequently repealing Directives 2001/77/EC and 2003/30/EC, 2009.

3. European Commission. Eurostat energy statistics, Shares 2012 results, 2013. Available at: http://epp.eurostat.ec.europa.eu/portal/page/portal/ energy/other_documents. (Accessed March 12, 2014).

4. Swedish Energy Agency. Transportsektorns energianvändning, 2012 (The use of energy in the transport sector in 2012). ES 2013:02, 2013. Available at: www. energimyndigheten.se (In Swedish). (Accessed April 10, 2014).

5. Government Offices of Sweden. Sweden's first progress report on the development of renewable energy pursuant to Article 22 of Directive 2009/28/ EC, 2011. Members States' progress reports, 2011 reports translated in English. Available at: http://ec. europa.eu/energy/renewables/reports/2011_en.htm.

(Accessed January 10, 2014).

6. Hansson J, Grahn M. Utsikt för förnybara drivmedel i Sverige (Prospects for renewable fuels in Sweden) Uppdatering och utvidgning av studien "Möjligheter för förnybara drivmedel i Sverige till år 2030 av Grahn och Hansson, 2010”, IVL Report B2083, 2013. Available at: http://spbi.se/wp-content/uploads/2013/03/ IVL_B2083_2013_final.pdf (In Swedish). (Accessed November 5, 2013).

7. Swedish National Audit Office. Biodrivmedel för bättre klimat - Hur används skattebefrielsen? (Biofuels for transport for a better climate - How is the tax exemption used?), RiR 2011:10. 2011. (In Swedish).

8. Government offices of Sweden. Regeringens proposition (Government bill) 2008/2009:163: En sammanhållen Klimat och Energipolitik - Energi (A coherent Climate and Energy policy - Energy), 2009. Available at: www.regeringen.se/sb/d/11033/a/122785 (In Swedish). (Accessed February 12, 2014).

9. Swedish Environmental Protection Agency. Underlag till en färdplan för ett Sverige utan klimatutsläpp 2050 (Basis for a roadmap for a Sweden without greenhouse gas emissions in 2050), Report 6537, 2012. Available at: http://www.naturvardsverket.se/Documents/ publikationer6400/978-91-620-6537-9.pdf? pid $=4965$ (In Swedish). (Accessed December 18, 2013).

10. Swedish Government Official Reports. Fossilfrihet på väg (On its way to fossil fuel independence). SOU 2013:84, 2013. Available at: http:/www.regeringen.se/ sb/d/108/a/230739 (In Swedish). (Accessed January 20, 2014).

11. Swedish Energy Agency. Övervakningsrapport avseende skattebefrielse för biodrivmedel år 2012 (Supervision report of the tax exemption for biofuels in 2012). 2013-03-19, 2013. Available at: http://www. energimyndigheten.se/PageFiles/26233/2013-0026\%20 Rapport\%20skattebefrielse \%20f\%C3\%B6r\%20biodri vmedel\%20\%C3\%A5r\%202012.pdf (In Swedish). (Accessed November 5, 2013).

12. Swedish Energy Agency. Hållbara biodrivmedel och flytande biobränslen under 2012 (Sustainable biofuels for transport and liquid biofuels during 2012). ET2013:06, 2013. Available at: www.energimyndigheten.se (In Swedish). (Accessed January 15, 2014).

13. Swedish Energy Agency. Långsiktsprognos 2010 (Long term prognosis 2010). ER 2011:03, 2011. Available at: www.energimyndigheten.se (In Swedish). (Accessed March 10, 2013).

14. Swedish Transport Administration. Delrapport transporter - Underlag till färdplan 2050 (Partial report - Basis for the roadmap for 2050). Publication no. 2012:224. ISBN: 978-91-7467-418-7, November 2012. Available at: http://publikationswebbutik.vv.se/ upload/6930/2012_224_Delrapport_transporter_under lag_till_fardplan_2050.pdf (In Swedish).

15. Profu. Roadmap för ett fossilbränsleoberoende transportsystem år 2030 (Roadmap for a fossil independent transport system 2030). For Svensk Energi and Elforsk. Version 2012-11-14, 2012. Available at: www.elforsk.se (In Swedish). (Accessed February 5, 2013).

16. KNEG. Hinder och drivkrafter för minskad klimatpåverkan från godstransporter (Obstacles and driving forces for reduced climate impact from freight transport). KNEG resultatrapport 2012. Klimatneutrala godstransporter på väg (KNEG), Trafikverket, Chalmers, Göteborgs miljövetenskapliga centrum (GMV), 2012. (In Swedish).

17. Swedish Transport Administration. Målbild för ett transportsystem som uppfyller klimatmål och vägen dit (Objectives for a transport system that fulfills climate targets and the way there). Publication number: 2012:105, 2012. Available at: http://publikat ionswebbutik.vv.se/shopping/ShowItem__5664.aspx. (Accessed May 7, 2013).

18. Swedish Government Official Reports. Slutbetänkandet från utredningen om förnybara fordonsbränslen: Introduktion av förnybara fordonsbränslen (Final 
report from the official investigation of renewable transport fuels: Introduction of renewable transport fuels), SOU 2004:133, 2004. Available at: http://www. regeringen.se/content/1/c6/03/67/01/bb423867.pdf (In Swedish). (Accessed February 19, 2013).

19. SP. Biorefinery Demo Plant in Örnsköldsvik, 2013. www.sp.se/sv/index/services/biorefinerydemoplant/ Sidor/default.aspx. (Accessed April 15, 2014).

20. Swedish Energy Agency. Produktion och användning av biogas år 2011 (Production and use of biogas in 2011). ES 2012:08, 2012. Available at: www.energi myndigheten.se (In Swedish). (Accessed January 12, 2013).

21. Kågeson P, Jonsson L. Var inom transportsektorn får biogasen störst klimatnytta? (Where in the transport sector will the largest climate benefit of biogas be achieved?). Report from Centre for transport studies, CTS Working Paper 2012:18, Stockholm, 2012.

22. Nordberg U. Biogas - Nuläge och framtida potential. Värmeforsk, ISSN 1653-1248. Stockholm, 2006.

23. Linné, M., Ekstrandh, A., Englesson, R., Persson, E., Björnsson, L., Lantz, M. Den svenska biogaspotentialen från inhemska restprodukter. Avfall Sverige, Svenska Biogasföreningen, Svenska Gasföreningen, Svenskt Vatten. Lund, 2008.

24. Luleå Tekniska Universitet, LTU Green Fuels, 2013. Available at: www.ltu.se/org/tvm/Avdelningar/LTUGreen-Fuels. (Accessed April 15, 2014).

25. Börjesson P, Lundgren J, Ahlgren S, Nyström I. Dagens och framtidens hållbara biodrivmedel - Underlagsrapport från f3 till utredningen om FossilFri Fordonstrafik (Current and future sustainable biofuels for transport-Report from f3 to the governmental investigation on Fossil fuel free vehicle transport). f3 Report 2013:13, 2013. Available at: http://www.f3 centre.se/sites/default/files/f3_borjesson_et_al_dagens_ och_framtidens_hallbara_biodrivmedel_slutversion_ rev_130620.pdf. (Accessed November 14, 2013).

26. BillerudKorsnäs. 2013. Available at: www.billerud.se/ Media/Pressmeddelanden/2013/BillerudKorsnas-avbryt er-forstudie-rorande-produktion-av-gron-olja-starkerfokus-mot-smartare-forpackningar/ (In Swedish). (Accessed April 2, 2014).

27. Fredriksson Möller B, Gillberg B, Huhtala R, Reinholdtzon A, Westlind G. 2013. Idestudie Bioraffinaderi Norrtorp 2013-09-17. (In Swedish).

28. Business Region Göteborg, Chalmers Gasifier, 2010. Available at www.businessregiongoteborg.com/down load/18.5cdb5cc912845f4210b8000716/Chalmers_ (Accessed April 3, 2014).

29. Marklund M, Weiland F, Hedman H, Westerlund S, Öhman M, Lundgren J. Renewable motor fuels from the forest industry via Pressurized Entrained flow Biomass Gasification. Final Report to the Swedish Energy Agency, 2012. Can be ordered from the Swedish Energy Agency (PO Box 310, SE-631 04 Eskilstuna, Sweden or registrator@energimyndigheten.se).
30. Preem. Pressrelease "Preem investerar 300 miljoner i ny produktionskapacitet för biodrivmedel", 2014. Available at: www.preem.se/templates/page_12120. aspx? newspageid=12143. (Accessed April 4, 2014).

31. Audi e-gas. Energy turnaround in the tank, 2013. Available at: www.audi.com/content/com/brand/en/vorspru ng_durch_technik/content/2013/10/energy-turnaroundin-the-tank.html. (Accessed April 9, 2014).

32. VW. Volkswagen Group Strategies. 0\% Emission, 100\% emotions, The road to Electromobility. 2012. Available at: www.volkswagenag.com/content/vwcorp/ info_center/en/publications/2013/01/0_Emissions_100_ Emotions.bin.html/binarystorageitem/file/Final_VW_ EMob_20120514_komplett_EN.pdf. (Accessed September 12, 2013).

33. Mohseni F. Power to gas: bridging renewable electricity to the transport sector. Licentiate thesis, KTH Royal Institute of Technology, Stockholm, 2012.

34. Nikoleris, A, Nilsson L. Elektrobränslen: en kunskapsöversikt. Report No 85. ISBN. 978-91-86961-11-4, Lunds University, Department of Technology and Society, Environmental and Energy Systems Studies, 2013. Available at: http://lup.lub.lu.se/luur/download? func $=$ downloadFile $\&$ recordOId $=3738215 \&$ fileOId $=37$ 38230 (In Swedish).

35. Ny Teknik. Charlotta von Schultz. Världens hajp runt algbaserat bränsle (The algae fuel hype), 2009. Available at: www.nyteknik.se/nyheter/innovation/forskning _utveckling/article674108.ece (Accessed April 13, 2014). (In Swedish).

36. Slade R, Bauen A. Micro-algae cultivation for biofuels: Cost, energy balance, environmental impacts and future prospects. Biomass Bioenergy 2013, 53:29-38.

37. Eriksson S. Towards a fossil free refinery. Presentation at the LU Biofuels Day, 21 May, 2013. Lund, Sweden.

38. Holland P. Preems strategi för att utveckla klimatvänliga biodrivmedel från restprodukter (Strategy of Preem to develop climate friendly biofuels from by-products and waste). Presentation by Petter Holland, president and CEO of Preem at Årets Bioenergidagar (organised by Svebio), Göteborg, Sweden, November 5, 2013.

39. European Commission. Proposal for a Directive of the European Parliament and of the Council amending Directive $98 / 70 / \mathrm{EC}$ relating to the quality of petrol and diesel fuels and amending Directive 2009/28/EC on the promotion of the use of energy from renewable sources, $\operatorname{COM}(2012) 595$ final, Brussels 17.10.2012, 2012.

40. Berndes G, Ahlgren S, Börjesson P, Cowie AL. Bioenergy and land use change: state of the art. WIREs: Energy Environ 2013, 2:282-303. doi: 10.1002/ wene.41.

41. Di Lucia L, Ahlgren S, Ericsson K. The dilemma of indirect land-use changes in EU biofuel policy - an empirical study of policy-making in the context of scientific uncertainty. Environ Sci Policy 2012, 16:9-19. 
42. Swedish Energy Agency. Långsiktsprognos 2012 (Long term prognosis 2012). ER 2013:03, 2012. Available at: www.energimyndigheten.se (In Swedish). (Accessed October 15, 2013).

43. Grahn M, Hansson J.. Möjligheter för förnybara drivmedel i Sverige till år 2030. (Possibilities for renewable fuels for transport in Sweden to 2030). Report for the Swedish Petroleum Institute, 2010. Available at: http://spbi.se/wordpress/wp-content/uploads/2010/09/ Chalmersrapport-SPI.pdf (In Swedish). (Accessed January 8, 2013).

44. European Parliament and Council. Directive 2009/30/EC of the European Parliament and of the Council of 23 April 2009 amending Directive 98/70/EC as regards the specification of petrol, diesel and gas-oil and introducing a mechanism to monitor and reduce greenhouse gas emissions and amending Council Directive 1999/32/EC as regards the specification of fuel used by inland waterway vessels and repealing Directive 93/12/EEC, 2009.

45. Ringbeck J, Koch V. Aviation biofuels: a roadmap towards more carbon-neutral skies. Biofuels 2010, 1:519-521.

46. Lichtenthaler FW, Peters S. Carbohydrates as green raw materials for the chemical industry. C R Chim 2004, 7:65-90.

47. Bengtsson S, Fridell E, Andersson K. Environmental assessment of two pathways towards the use of biofuels in shipping. Energy Policy 2012, 44:451-463.
48. Swedish Energy Agency. Analys av marknaderna för biodrivmedel - Aktuella marknadsfrågor för första och andra generationens biodrivmedel (Anaysis of the market for biofuels - Current market issues for first and second generation biofuels). ER 2012:29, 2012. Available at: www.energimyndigheten.se (In Swedish). (Accessed February 9, 2013).

49. European Environment Agency (EEA). How much bioenergy can Europe produce without harming the environment? EEA Report No 7/2006, ISBN 92-9167 -849-X, ISSN 1725-9177, 2006. Available at: http:// www.eea.europa.eu/publications/eea_report_2006_7.

50. BIL Sweden. Trade organization for manufacturers and importers of cars, trucks and buses in Sweden, 2013. Available at: www.bilsweden.se (Accessed March 1, 2013).

51. Svenska Petroleum och Biodrivmedel Institutet. Statistics fuel stations, 2013. Available at: http://spbi.se/ statistik/forsaljningsstallen/forsaljningsstallen-med-for nybara-drivmedel (Accessed March 1, 2013). (In Swedish).

52. European Commission. Background facts to directive 2009/28/EC of the European parliament and of the Council of 23 April 2009, on the promotion of the use of energy from renewable sources and amending and subsequently repealing Directives 2001/77/EC and 2003/30/EC, 2014. Available at: www.notisum.se/rnp/ eu/lag/309L0028.htm (Accessed June 10, 2014). 